\title{
KETIKA ORANG SENI MENYOAL MASYARAKAT: TEGANGAN DIALEKTIK ANTARA MOMEN KEINDAHAN DAN KEBENARAN
}

\author{
Kasiyan \\ Jurusan Pendidikan Seni Rupa, Universitas Negeri Yogyakarta \\ E-mail: kasiyan@uny.ac.id
}

\begin{abstract}
Abstrak
Tulisan ini hendak mengedepankan kajian perihal fenomena dialektis antara seni dengan masyarakatnya, yang sampai saat ini kerap menyisakan persoalan secara sosiologis. Sebagai bagian dari entitas sosial yang menyejarah, seni sebagaimana halnya dengan kebudayaan apa pun lainnya, keberadaannya senantiasa berada dalam ruang medan dan sekaligus arena produksi kulturasi, yang secara dialektis membentuk serangkaian proses habituasi kesadarannya yang tak pernah mengenal henti. Di antara sekian pluralitas tegangan pemaknaan terhadap realitas seni di masyarakat tersebut, yakni ketika seni lebih dimaknai sebagai jagad dan momen keindahan yang kemudian menghadirkan konstruksi "realisme sosial" di satu sisi, dan lebih mengedepankan momen kebenaran yang mendorong hadirnya konstruksi "realisme sosialis" di sisi yang lainnya. Dua kutub interseksi pemaknaan seni dan masyarakatnya yang dikotomis ini, sejatinya bisa didamaikan di antaranya dengan perspektif Platonian dan juga Aristotelian, yang konstruksi gagasannya cenderung mengafirmasi kesetaraan antara diktum keindahan dan kebenaran.
\end{abstract}

Kata kunci: dialektika, seni, masyarakat, momen keindahan, momen kebenaran

\section{WHEN ARTISTS ASK QUESTIONS ABOUT SOCIETY: THE DIALECTICAL TENSION BETWEEN MOMENT OF BEAUTY AND TRUTH}

\begin{abstract}
This paper would like to discuss the dialectical phenomenon between arts and society that until today leaves sociological problems. As a part of a historical social entity, arts similar to other elements of culture is always in the midle of a cultural production area, which dialectically forms a sets of never ending habitual processes of consciousness. One of the tensions of plurality related to the understanding of art reality in the society is the fact that art is interpreted as the universe and moment of beauty which then presents the construction of 'social realis' on one side and puts forward the moment of truth encouraging the the appearance of 'socialist realism' on the other one. This dichotomy of interpretation of art and its society can be reconciled by means of Platonian perspective and Aristotelian perspective of which its construction of ideas tends to affirmthe dictum of beauty and truth equally
\end{abstract}

Keywords: dialectics, art, society, the moment of beauty, the moment of truth

\section{PENDAHULUAN}

Kalau membaca topik tulisan ini, sebenarnya penulis merasa tidak cukup berada dalam hitungan kapasitas dan kapabilitas (orang seni) sebagaimana dimaksud, karena sekali- kali penulis menyadari bahwa penulis tidak pernah termasuk dalam ordinat sebagai orang seni, tatkala menggunakan kecenderungan determinisme klasik selama ini, yakni bahwa yang dinamakan 'orang seni' itu, adalah identik 
dengan seniman atau minimal kritikus seni. Penulis berada di luar kedua lingkaran itu. Kalau penulis hendak berbagi dalam konteks kaitan ini, lebih dikarenakan berangkat dari keyakinan, bahwa penjangkaran makna ordinat orang seni, mestinya tidak sesempit itu, akan tetapi mestinya dalam perpsktif yang lebih terbuka, sehingga juga terbuka untuk melibatkan perhitungan elemen strategis lain yang lebih luas. Sebab, memang itulah kodrat semesta hidup budaya, termasuk juga seni tentunya, yang "the thing"nya itu (meminjam istilahnya Martin Heidegger) (Graham Harman, 2011) hanya dapat benarbenar digenggam secara bermakna, ketika memang eksistensinya mampu meng-ada dalam konstruksi inklusif-terbuka.

Oleh karena itu, sekecil apa pun keberadaan dan posisi siapa pun dalam konteks makna inklusivitas ini, secara ideal mestinya tetap menjadi bagian penting bagi berbagai kemungkinan pembangunan kehidupan berkebudayaan termasyk tentunya berkesenian yang lebih menjanjikan. Karenanya pula, penulis sebagai salah satu representasi posisi yang berada di pinggiran (peripheral), terkait dengan topik di atas, mempunyai peluang yang sama strategisnya, untuk berbagi pemahaman terkait dengan bagaimana realitas jalinan mengada-nya (being) seni dalam masyarakat kita selama ini, khususnya lagi bagaimana selama ini (orang) seni berbicara atau memaknai tentang masyarakatnya.

\section{MASYARAKAT SEBAGAI MEDAN DAN ARENA SENI}

Istilah "masyarakat" hampir niscaya menjadi salah satu tematik sentral, ketika seni diperbincangkan, karena memang realitas seni itu kodratinya bukannya sesuatu yang a historis, melainkan sebaliknya: ia kapan pun dan di mana pun beradanya, adalah merupakan sebuah risalah yang menyejarah. Ketika bersinggungan dengan kosa kata sejarah inilah, maka terminologi "masyarakat" seolah menjadi mirip satu dari dua sisi keping mata uang, yang kehadirannya mesti niscaya. Artinya, di antara satu dengan lainnya keberadaannya saling mempersyaratkan. Sejarah tidak akan pernah ada tanpa masyarakat, demikian juga sebaliknya, masyarakat tidak pernah terklarifikasi keberadaannya tanpa adanya sejarah. Karenanya, seni sebagai realitas yang historis, sudah sejak sangat lama menegaskan konsep gambaran jalinan keintiman dengan masyarakatnya.

Meski dalam pasang surutnya dinamika wacana sejarah seni di masa lampau, sempat ada antitesis atau penyangkalan atas hal tersebut, dengan munculnya pemikiran atau faham yang mencoba meyakini bahwa realitas seni adalah kebalikannya, yakni sebagai sebuah wilayah otonomi. Dalam konsep dan faham ini, seni didudukkan seolah-olah lepas atau keluar dari kepompong masyarakatnya. Ia (seni), kemudian hanya menjadi urusan senimannya sematamata. "Why should art be good for something when it is good in itself", demikian jargon yang membungkusnya (Soedarso, 1988:20; Michael Davis, 2011:61; Ray Van De Walker, 2012). Faham inilah, yang kemudian dalam sejarah seni melahirkan konsep l'art pour l'art (art for art sake) atau "seni untuk seni" (Gene H. Bell-Villada, 1998; Elizabeth Prettejohn, 2007; Ellen Winner, Thalia R. Goldstein and Stéphan Vincent-Lancrin, 2013), yang pemaknaannya mencoba menempatkan seni sebagai sebuah entitas yang seolah berjarak dan bahkan tak berkepentingan dengan konteks sosial masyarakatnya. Dalam konsep ini, entitas seni diyakini sebagai realitas ahistoris yang seolah tak punya kaitannya dengan dimensi sosiokultural masyarakatnya.

Namun tesis tersebut, tidak cukup kuat untuk dipertanggungjawabkan dalam batu ujian sejarah yang panjang di masyarakat. Artinya, jargon "seni untuk seni" tersebut, ternyata tetap tinggal jargon, yang sulit ditemukan verifikasinya dalam jagad empirisnya secara nyata. Bahkan akhirnya, sejarah tetap meneguhkan bahwa, seni dalam dimensi makna sosiologis — dalam artian bahwa wacananya harus menjadi satu dengan kepompong masyarakatnya- inilah, yang tetap menjadi arus utama tesis seni yang eksis sampai hari ini. Seni dengan demikian adalah lebih bermakna sebagai realitas atau fenomena historis (art as a historical phenomenon) (Fred S. Kleiner, 2009:1). 
Fenomena ini menjadi demikian mudah untuk difahami sebenarnya, karena masyarakat memang telah dipostulatkan sebagai ruang medan dan juga arena, di mana segala representasi kebudayaan manusia-termasuk juga seni tentunya - itu ada, tumbuh, berkembang. Pemahaman yang terakhir ini mendapatkan rujukannya yang cukup komprehensif, di antaranya melalui gagasan pemikiran seorang filsuf Prancis Pierre Bourdieu (1996; 1997; 2013) misalnya, yang meneguhkan bahwa sejatinya setiap upaya representasi dalam setiap teks budaya apa pun (termasuk seni misalnya), akan selalu berada dalam lintasan (trajectory) di masayarakat yang diistilahkan sebagai "medan" dan sekaligus "arena" produksi kultural.

Sebagai "medan seni" masyarakat terperikan dalam makna sebagai konteks atas setiap representasi teks (seni) yang memanifesto dirinya. Artinya, setiap ekspresi dan representasi teks seni hanya dapat dimengerti, jika dan hanya jika telaahannya melibatkan konteks historis dan juga sosiologis aura habitat atau lingkungan tempat teks tersebut dihadirkan. Tanpa melibatkan medan seni (masyarakat) sebagaimana di maksud, mustahil sebuah makna atas teks seni dapat digenggam secara komprehensif.

Sementara itu, terminologi masyarakat sebagai "arena seni" lebih auratik menyiratkan pesan, bahwa ia (masyarakat) itu, di samping sebagai konteks yang membungkus aura setiap teks seni itu, juga sebenarnya sebagai tempat seni itu sendiri direpresentasikan. Ia (masyarakat), dalam hal ini bukan hanya sebatas bermakna lingkungan, melainkan lebih dari itu, ia adalah panggung, kanvas tempat pentas perhelatan seni itu sendiri disajikan. Dalam pengertian inilah, bahkan akhirnya keberadaannya (masyarakat) menjadi semakin mutlak adanya. Sebagaimana halnya dengan teater tidak akan pernah dapat dihelatkan, jika tanpa panggung (arena), demikian juga lukisan tidak pernah akan tersaji, tanpa kanvas (tempat membuncahkan medium rupa). Dengan demikian, kosa kata antara "seni" dan "masyarakat" yang bermakna tidak hanya dalam wacana sebagai medan, tetapi juga sekaligus arena ini, menjadi sebuah justifikasi kenicayaan yang tak mungkin dapat terhindarkan.

Dalam konteks ini pula karenanya eksistensi seni sebagaimana halnya dengan setiap teks kebudayaan apa pun lainnya selalu berada dalam ruang dan dinamika realasional tegangan kontestasi yang tiada pernah henti demi memperebutkan ruang medan dan arena kulturasi. Konstruksi kultural inilah yang kemudian menghadirkan apa yang diistilahkan Bourdieu (2013) sebagai habitus. Secara terminologis, habitus dapat dimaknai sebagai semacam sistem disposisi yang di dalamnya terkandung kecenderungan kesadaran dalam memandang dan memahami dunia sosial di sekitar mereka dan bagaimana strategi reaksi yang diperankan terhadapnya (Lizardo, 2004). Dalam proses habituasi inilah, karenanya selalu tersedia sekian banyak peluang dan kemungkinan bagi hadirnya pelbagai jenis dan varian kesadaran dalam mendialektikakan dan memaknai setiap teks kebudayaan (Mathieu Hilgers, 2009), tentunya termasuk juga dalam jagad seni dan kesenian. Bahkan dalam tilikan yang lebih jauh lagi dan dalam, jagad sosial itu sejatinya adalah sebagai ruang dimana tempat berlangsungnya aneka kompetisi dan kontestasi budaya dan termasuk juga seni diselenggarakan (Pierre Bourdieu, 1989; Philippe Coulangeon \& Julien Duval, 2014; Roy Nash, 1990; KyungMan Kim, 2015).

Oleh karena itulah, kita menjadi faham ketika para sosiolog seni dengan amat tegas mengungkapkan bahwa "art as social product" (Janet Wolff, 1981; Arnold W. Foster \& Judith R. Blau, 2011; Julia Rothenberg, 2014). Dalam pemahaman seni sebagai produk sosial dengan segala potensi dinamika eksistensinya di masyarakat itulah, karenanya kemudian berkembang penolakan suatu gagasan seni yang bersifat tradisional-romantik, yang semata-mata disamdarkan pemaknannya sebagai hasil karya yang tak terjelaskan, yang seolah melampaui pelbagai diskursus atau wacana sosial. Sebaliknya, pandangan yang lebih berterima kemudian, adalah gagasan yang lebih menempatkan seni sebagai produk kreatif, sebagai sebuah gugusan konstruksi yang 
kompleks dari sejumlah faktor-faktor historis sosial yang nyata dan menyelimutinya (Wolff, 198; Tony J. Wilkinson, 2003:3; Margaret Lazzari \& Dona Schlesier, 2011; P. McIntyre, J. Fulton, \& E. Paton, 2016:20).

\section{INTIMITAS SENI DAN MASYARAKAT: TEGANGANANTARAREALISME SOSIAL DAN REALISME SOSIALIS}

Keniscayaan realitas atas ketidakterpisahannya antara seni dan masyarakat sebagaimana dimaksud, pada dataran selanjutnya membuahkan sebuah jalinan teks keintiman. Keintiman antara seni dan masyaraat ini, wacananya paling tidak dapat ditemukenali dalam format atau model mainstream faham yang dikenal dengan 'Realisme'. Sejarah Realisme bermula di Eropa pada abad pertengahan sejalan dengan fajar modernisme mulai terbit (Don Ihde, 1991:61; Robert Allan Maxwell, 2010), yang kemunculannya sebagai rekasi atas faham romantisisme yang terlalu memberi tekanan pada emosi (Simon Gikandi, 2012; Christopher Caudwell, 2015:106), dengan tokoh-tokohnya antara lain Theodore Gericault dan Eugene Delacroix (Allison Lee Palmer, 2011:171), sehingga seringkali mengaburkan makna di balik permukaan yang ada.

Realisme dalam bidang sastra, menurut Georg Lukacs dapat dirunut dari Eropa (Inggris) pada awal abad ke-19 dan di Perancis menjelang akhir abad ke-18 (Ibe Karyanto, 1997:39), sedangkan di Rusia pada akhir abad ke-19 (Ivan Katchanovski, Zenon E. Kohut, Bohdan Y. Nebesio, \& Myroslav Yurkevich, 2013:492). Kemudian dalam konteks Indonesia, sejarah realisme dalam ranah seni rupa berawal dari Raden Saleh (1816-1880), yang skill melukisnya banyak dipelajari selama lebih dari 25 tahun pengembaraannya di Eropa (Claire Holt, 2000:237; Susie Protschky, 2011:54; Shireen Naziree, 2013; Yvonne Spielmann, 2017:63). Realisme dalam seni rupa, paling tidak dapat ditelusur maknanya dari pernyataan Gustave Coubert: "Show me an angel and I will paint one" (Herbert Read, 2000;69; David M. Stone, 2017:128; M. Melissa Wolfe, 2017:134). Dalam pernyataan tersebut, diyakini bahwa segala yang tampak/nyata dapat direpresentasikan oleh perupa realis, sebab realisme dalam seni rupa memang bermaksud menampilkan realitas dalam karyanya, sebagaimana halnya filsafat realisme yang mendasarkan keyakinan secara eksistensial atas eksistensi objektif dari segala sesuatu (Herbert Read, 2000;69).

Dalam perjalanan sejarah perkembangannya, faham realisme tersebut, kemudian terbelah menjadi dua model arus utama, pertama, dikenal dengan "realisme sosial", dan kedua, adalah "realisme sosialis". Dua konsep itu berbeda, meski dalam masyarakat maknanya sering dikacaubalaukan, dengan cara menyamakannya.

Pertama, realisme sosial, sebagai sebuah faham yang mencoba mendekatkan seni dengan konteks masyarakatnya, namun makna kedekatan tersebut, nyaris tanpa pretensi dan emosi yang yang menunjukkan adanya unsur keterlibatan atau keberpihakan. Dalam hal ini, seni yang direpresentasikan oleh orang seni (seniman), hanya melihat realitas alam beserta sosial budayanya yang tergelar, untuk kemudian direfleksikan dalam wujud karya. Seni lebih mirip sebuah cermin bisu, yang tugasnya hanya memantulkan gambar (bayangan) atas objek yang ada di depannya, tanpa adanya kepentingan sedikit pun upaya untuk memberikannya makna. Citra cermin (mirror image) yang melekat dalam diri konsep seni yang demikian, akhirnya dalam memaknai sebuah setting konteks (masyarakat) itu, tak lebih dari sebuah fenomena yang hampa udara, kosong, dan tuna makna (meaningless). Kalau toh dipaksa ada maknanya, makna yang terpancarkan dalam pemahaman seni yang berbingkaikan "Realisme Sosial" ini, tak lebih dari makna artifisial fisik yang me-"realita" (yang tampak), dan bukannya makna yang dijangkarkan pada aras substansial yang meng"idealita" (yang tersembunyi).

Dalam landscape historisitas keberlangsungan kehidupan seni di Indonesia misalnya, untuk tipologi seni ini, dengan sangat gamblang misalnya dapat ditunjuk terminologi representasi estetika Mooi Indie (India Molek), yang dimotori oleh beberapa pelukis seperti Abdullah Surio Subroto (1878-1941), Mas Pirngadi (1875- 
1936), Wakidi dan Basuki Abdullah. Demikian juga yang diusung oleh Tjokorde Gde Agung, Walter Spies, dan Rudolf Bonnet dengan Pita Maha-nya di Bali (1925) (Lesley Reader \& Lucy Ridout, 2002:202; Adrian Vickers, 2012:24), yang kesemuanya itu, menempatkan realitas terutama alam dan sosial budaya sebuah masyarakat dalam pemaknaan artifisial yang serba eksotik, menarik, mengagumkan, dan menyenangkan (Miklouho L-Maklai, 1988:15).

Mereka, para penganut faham realisme sosial itu, dengan demikian tidak mau berkepentingan menangkap dan mengungkap di balik setiap penampakan artifisial yang ada dalam setiap teks alam dan kebudayaan yang ada. Sebaliknya, mereka hanya terkagumkagum pada penampakan-penampakan estetis, semisal romantisme pemandangan alam yang luar biasa dari desa-desa di masa lalu, dengan segenap hamparan sawah, gunung membiru, yang diselimuti kabut tipis di pagi hari yang dingin atau sore hari yang hangat, pemandangan laut lepas yang masih membiru mendayu, juga eksotika pemandangan gadis-gadis cantik Bali (yang masih berkultur desa dulu) yang dengan sangat lugunya, kemana-mana bertelanjang dada, juga ketika mereka beramai-ramai sedang mandi bersama di se antero kali desa yang bening kilauan airnya.

Keserbatakjuban seniman akan kedahsyatan estetis sosial yang tertampak di permukaan itulah, akhirnya telah menenggelamkan representasi karya-karya seni mereka, menjadi semacam budak-budak estetika semata. Hal inilah, yang dalam sejarah banyak ditentang di antaranya oleh seorang Soedjojono, dengan mengusung spirit baru dalam faham realisme, yakni realisme sosialis, dengan menyeyogiyakan keyakinan baru, yakni bahwa mestinya seni itu harus mampu menghadirkan auratik ruang batin di kedalaman. Ia (seni) itu mestinya menjadi sebentuk penanda kehadiran dari penampakan jiwa (jiwa ketok) (Yvonne Spielmann, 2017). Sejalan dengan pandangan tersebut, Moshe Barasch (2000:317) menyampaikan pendapatnya sebagai berikut.
One of the conditions that is describe as an inner necessity is that work of art touch the spectator. To put is rather general requirement in Kandinsky's specific terms: thus it is clear that the harmony of forms can only be based upon the purposeful touching of the human soul.

Dalam konteks pemaknaan inilah, kemudian lebih jauh lagi berkembang pemahaman bahwa seni itu harus terlibat, berpihak kepada masyarakatnya. Faham ini banyak dikembangkan kemudian lewat proyek "Persagi" (Persatuan Ahli Gambar Indonesia) misalnya, sebagai sebentuk komitmen dunia seni membangun semangat keberpihakan atau keterlibatan dengan nasionalisme yang terbuka melalui media seni dan budaya.

Oleh karena itulah, terkait dengan faham kedua, yakni realisme sosialis, mencoba membangun makna kedekatan antara seni dengan masyarakatnya itu, tidak terbatas pada pemahaman pada dimensi artifisial yang nampak di permukaan semata, melainkan lebih dalam dari itu, yakni mencoba menyelami sesuatu yang substansi, baik yang menyangkut masalah nilai-nilai maupun spirit ideologi. Dalam hal ini, makanya seni tidak mau hanya sebagai cermin, saksi yang membisu, melainkan sedapat mungkin berperan dalam sebuah intensitas keterlibatan atau keberpihakan yang meng"aksi".

Spirit yang terkandung dalam realisme sosialis ini, dalam diametrikal tertentu karenanya relatif sebangun dengan perspektif Aristotelian, di mana memandang seni bukan sekedar menghasilkan karya demi karya, namun melampaui dari semua itu adalah, ia bahkan dihajatkan sebagai alternatif medium pelbagai proyek pencerahan, yang diistilahkan lain sebagai pemurnian jiwa manusia dan juga kebudayaannya (Stephen Halliwell, 1986:54; Roman Meinhold, 2015). Konsep pemurnian inilah, yang kemudian disebut Aristoteles sebagai ruang "katarsis" (Bagoes P. Wiryomartono, 2001:22; E. Belfiore, ýO. Bennett, 2008:81; Leon Golden, 2017). Ketika menelisik alir nalar realisme sosialis dengan 
konstruksi pemakanaan yang demikian itulah, karenanya, risalah gagasan realisme sosialis ini, konon juga berkelindan erat dengan gagasan Marx dan Engels, yang banyak berbasiskan pada seputar persoalan perjuangan kelas sosial dalam arti luas, yang formulanya banyak dibingkau dengan diktum misalnya materialisme historis, materialisme dialektis, dan teori nilai lebih (theory of surplus value) (Karl Marx, 2000).

Seni yang berilhamkan faham realisme sosialis itu, makanya sangat dekat dengan substansi realitas sosial tempat ia (seni itu) berada. Di situ para seniman bisa mengekspresikan pekik dan teriakan diri dengan segala macam politik resistensi, kritik, protes, gerakan perlawanan, dan bahkan berusaha secara bersama-sama dengan pranata sosial lainnya mengubah masyarakat sebagaimana yang diidealkannya. Dalam dunia seni lukis misalnya, konstruksi nalar seperti ini misalnya dapat dilihat dari representasi karya lukisan Djoko Pekik Berburu Celeng (1998) yang konon sangat dekat melukiskan keadaan masyarakat di sekitar runtuhnya rezim Soeharto. Kemudian dalam dunia teater misalnya, kita mengenal Teater Koma, yang keseluruhan komitmen karya yang dipentaskannya selama ini, betapa sarat dengan misi keberpihakan dan kritik sosial yang amat tajaam, terutama terhadap kekuasaan. Demikian juga halnya dalam dunia sastra misalnya, semenjak berhembusnya angin reformasi kebudayaan, para penerbit berlombalomba menampilkan karya-karya sastra dunia yang di masa sebelumnya kerap dianggap sebagai sesuatu yang kiri dan subversif, seperti milik Gabriel Garcia Marques, Pablo Neruda, Naquib Mahfous, Nestor Paz, dan lain-lain.

Persoalannya kemudian adalah, sebagaimana halnya yang terjadi dalam faham realisme sosial, ternyata sebentuk kebulatan komitmen keterlibatan atau keberpihakan kepada masyarakat yang digenggam oleh faham realisme sosialis tersebut, juga akhirnya membuahkan wacana yang nyaris sama absurditasnya, hanya dengan varian yang berbeda saja. Absurditas yang dimaksud adalah berpusat pada persoalan keseimbangan (equalibrium) atau equality yang mesti dibangun oleh setiap representasi karya seni, yakni antara nilai estetika (yang tampak) dengan nilai pesan substansi (yang tersembunyi). Kalau dalam realisme sosial, ketidakseimbangan representasi seninya itu terletak pada pilihan muatan lebihnya pada dimensi estetikanya, dan sebaliknya kering akan nilai pesannya. Sementara itu persoalan ketidakseimbangan absurd yang terjadi dalam realisme sosialis, adalah ketika representasi keindahan estetis menjadi kerap berpotensi ditenggelamkan oleh idealisasi dari domain pesannya.

Terkait dengan konstruksi pemaknaan seni yang terakhir bahkan seringkali, sejarah menunjukkan bahwa keberpihakan itu dalam risalahnya, juga tidak pernah mempunyai kebenaran yang universal maknanya, melainkan yang terjadi justru lebih bersifat fragmentaris dan segmentatif, sehingga seni banyak yang mengabdi pada siapa yang memegang kendali. Contoh akan hal ini, yang teramat klasik dalam sejarah seni di Indonesia misalnya, adalah terkooptasinya seni dalam fragmentasi politik di sekitar tahun 60-an, yang pada waktu itu politik Indonesia dikuasai oleh komunisme. Akhirnya potensi laten seni, yang mestinya mampu berdiri bebas, justru jatuh terjebak menjadi agen dan budak propagandis, seperti yang dialami oleh para seniman yang tergabung dalam Sanggar Boemi Taroeng, Seniman Indonesia Muda, dan Pelukis Rakyat, yang terwadahi dalam kelompok seniman yang dikenal dengan sebutan Lembaga Kebudayaan Rakyat (Lekra). Di sinilah, seni akhirnya sangat tampak di samping tidak berdaya, juga telah kehilangan salah satu ikon kodratnya, yakni aura estetik atau keindahannya.

\section{SENI: TEGANGANANTARAMOMENT OF TRUTH DAN MOMENT OF BEAUTY}

Berdasarkan realitas absurd cara mang"ada"nya seni dengan masyarakatnya-yang notabene juga sebagai hasil seniman membaca, membicarakan, atau memaknai masyarakatnya sebagai terpapar di atas, maka ada satu pertanyaan menarik, bagaimanakan seyogiyanya seni itu meng-"ada" di tengah-tengah realitas sosial yang semakin ditandai dengan kecenderungan pelbagai krisis kebudayaan yang ada. Dalam ungkapan lain, yakni bagaimanakah semestinya 
orang seni (seniman) membaca, membicarakan, atau memaknai masyarakatnya? Inilah kiranya beberapa pertanyaan fundamental yang jawabnya masih akan terus diburu melalui jalan berliku. Perburuan penjelasan dalam rangka untuk mengklarifikasi jawaban atas pertanyaan seperti itu, secara ideal akan tetap dijangkarkan pada dua model formulasi seni sebagaiama halnya juga telah dipaparkan di atas. Hanya bagaimana berbagai absurditas di antara masing-masing faham - antara realisme sosial dan realisme sosialis - itu dapat diminimalisir sedemikian rupa, hingga antara satu sisi otoritas seni yang mesti estetik, tidak terkalahkan dengan sisi otoritas pesannya yang juga mesti hadir mengada.

Bukankah memang enigma absolut seni itu justru terletak dalam keyakinannya yang paradoksal itu: yakni bahwa di satu sisi seni itu adalah ciptaan manusia belaka dengan segala keterbatasannya, namun mampu memunculkan schein des scheinlosen, penampakan dari sesuatu yang tidak tampak, munculnya sesuatu yang infinite, tanpa batas dalam suatu keterbatasan (Noel Cox, 2007:72; Bernard Bosanquet, 2015). Di sinilah kemudian seni justru mampu hadir, mengada sebagai suatu kebenaran yang melampaui dunia empiris yang kerap sarat dengan keterbatasan (A. Bagus Laksana, 2001:24; Abraham Kuyper, 2009:154). Selalu akan ada ketegangan pergulatan di antara dua kutub itu, yakni ketegangan antara mau menempatkan seni dan estetika sebagai sebuah bidang yang otonom, dan di sisi lain keinginan menempatkan estetika dalam haru-biru keberpihakan pada perjuangan masyarakatnya. Antara mau menjaga kemurnian estetika, dan sebaliknya mengadakan kompromi dengan situasi. Antara menjaga seni sebagai moment of beauty (Mike Fleming, Liora Bresler, \& John O’Toole, 2014:320) dan sebaliknya menempatkan seni sebagai moment of truth.

Namun sebenarnya, kedua otoritas pandang tersebut tidak harus selalu dikonfrontirkan secara tajam, apalagi absolut. Karena, sebenarnya kodrati hidup manusia dan kebudayaannya itu, termasuk seni juga menjadi bagian di dalamnya tentunya, sejatinya selalu dapat disolusi dengan jalan kompromi, demikian juga halnya dengan yang terjadi pada dialektika antara moment of beauty dan moment of truth dalam karya seni. Bahkan penegasan ide kesadaran atas pentingnya kompromitas yang seimbang dalam memandang dan memaknai antara otonomi "yang indah" dan "yang benar" ini, jauh-jauh sudah diretas embrionya sejak era Plato di Athena Yunani, ketika zaman belum beridentitaskan masehi. Plato yang hidup sekitar tahun 427 SM hingga 347 SM misalnya, dalam salah satu karya monumentalnya Dialog Ion, mampu merengkuh keduanya - antara "yang indah" dan "yang benar" tersebut ke dalam kesatuan pemahaman yang harmoni dan tak terpisahkan (Alexander Roberts, 2007:467; Afifeh Hamedi, 2014; Paul Friedlander, 2015:218). Keindahan dan kebenaran bagi Plato adalah sebulat bola cahaya yang tidak terpisahkan. Kebenaran bagi Plato adalah risalah perihal ketersingkapan "yang ada", dalam arti hadir dan mengalir sebagai kejadian yang memperlihatkan jati dirinya. Penampilan keindahan bagi Plato adalah idea atau eidos yang mengikuti prinsip-prinsip hakiki berangkat dari kesempurnaan. Idea atau eidos bagi Plato adalah ada/berada, yang indikasinya diperlihatkan dengan keesaan, persetubuhan, dan kesempurnaan (Wiryomartono, 2001:8-10). Kristalisasi perihal dialektika konsep seni dan kebudayaannya Plato sebagaimana dimaksud, selama ini kerap dipahami sebagai "teori mimesis" (Lloyd P. Gerson, 1999:327; Max Paddison, 2010; Ajda Şenol, 2014; Gilberto Scaramuzzo, 2016; Nicolae Babuts, 2017:2; Denis Dutton, 2009:33), yang substansinya menyoal perihal refleksi fenomena kesadaran yang terkait dengan kenyataan.

Oleh karena itu, dalam perspektif Platonian ini, seni yang diidealkan sebagai gairah untuk merepresentasikan keindahan itu sejatinya adalah kebenaran ada/berada itu sendiri. Karya seni merupakan tiruan dalam rangka menghadirkan kebenaran ada/berada dalam wilayah yang sengaja dibuat manusia sebagai pertunjukan. Karenanya, lebih jauh lagi dalam pandangan Plato, para artis atau seniman sejati selalu memiliki ketertarikan yang tulus pada realitas, bukan tiruan atau kepalsuan. Realitas yang 
dimaksudkan dalam hal ini adalah pengetahuan sejati atau eksistensial tentang sesuatu yang ada. Oleh karenanya, apa yang dilakukan seniman sejati adalah mengenali pengetahuan sejatinya dari setiap pokok cipta karyanya. Setelah pemahaman pengetahuan sejati ini utuh, barulah cakrawala nama rupa (estetika) yang beragam dan bervariasi terbuka. Dengan pemahaman inilah, makanya sebuah representasi seni yang ideal, diharapkan akan senantiasa berkepentingan untuk menyandingkan antara yang namanya kenikmatan (arts as pleasure) (Christopher Butler, 2005; Gordon Graham, 2006:6), sebagai buah kristalisasi dari pancaran nilai-nilai keindahan dan kebenaran. Pandangan ini sekali lagi meneguhkan keyakinan, bahwa yang benar itu adalah indah, dan demikian juga sebaliknya yang indah itu adalah benar.

Tinggal persoalannya kemudian adalah, mampu[mau]kah orang seni terutama di era konteks zaman kekinian yang selalu berkepentingan untuk membaca realitas ada/beradanya masyarakat itu, hingga buah pembacaannya itu menghasilkan representasi seni, yang dapat ditelisik buliran kebersatuannya antara dua terminologi yang indah dan yang benar, dalam sebuah kebersatuan simfoni yang harmoni. Terutama lagi, ketika kenyataan zaman di era kekinian, betapa kebudayaan dan juga kesenian kerap dihantui dan didera oleh remuk redam deru krisis yang kian memperihatinkan.

\section{KESIMPULAN}

Berdasarkan pokok-pokok pikiran yang telah disampaikan di atas, kiranya bisa disampaikan catatan bahwa yang namanya seni sebagaimana halnya dengan entitas budaya apun lainnya, keberadaannnya senantiasa berada dalam formasi dialektis yang dinamis. Ia, seni itu, sejatinya tak pernah memiliki konstruksi yang sebaliknya statis, sehingga senantiasa membuka peluang bagi serangkaian proyek penafsiran yang terus berulang. Fenomena ini hanya dapat dimaknai manakala berangkat dari keyakinan keniscayaan bahwa yang namanya seni itu juga sebagaimana entitas kebudayaan lainya keberadaannya senantiasa berada dalam ruang medan dan sekaligus arena produksi kulturasi, yang secara dialektis membentuk serangkaian proses habituasi kesadarannya yang tak pernah mengenal henti. Inilah yang kemudian dalam perspektif Bourdieuian akrab diistilahkan sebagai konstruksi habituasi.

Adapun, di antara sekian pluralitas tegangan pemaknaan terhadap realitas dan fenomena seni di masyarakat tersebut, secara klasik dan krusial yang seolah tak pernah akan berujung sampai saat ini adalah, ketika seni mesti dimaknai dan difahami sebagai jagad dan momen keindahan (arts as a moment of beauty) di satu sisi, dan di sisi yang lainnya lebih menempatkan pemaknaan dan juga pemahaman seni lebih sebagai momen kebenaran (arts as a moment of truth).

Ketika lazimnya diktum ketegangan itu senantiasa menempatkan habitus kesadaran dalam formulaik yang oposisi dan berlawanan, sebenarnya jalan keluar yang paling elegan adalah sebagaimana klasiknya, adalah tetap menempatkan sudut pandang keduanya dalam format keseimbangan. Dalam konstruksi alir nalar yang terakhir ini, mencoba memaknai seni dalam kaitannya dengan konteks kehadirannya di masyarakat itu, lebih sebagai gugusan gagasan ideal sebagaimana yang diyakini dalam perspektif Aristotelian, yakni keindahan (arts as a beauty) itu tak kan pernah dipisahkan pengertiannya dengan kebenaran (arts as a truth). Konstruksi pemikiran dalam format keseimbangan seni ini, yakni antara kutub keindahan dan juga kebenaran, tentunya akan senantiasa menjadi tegangan dialektik yang tak kan berkesudahan. Justru di situlah di satu sisi letak daya enigmatic-nya seni yang penuh misteri dan selalu terus menerus digairahi.

\section{DAFTAR PUSTAKA}

Babuts, Nicolae. 2017. Mimesis in a Cognitive Perspective: Mallarme, Flaubert, and Eminescu. London: Routledge.

Barasch, Moshe. 2000. Theories of Art: From Impressionism to Kandinsky. Volume 3. London: Psychology Press.

Belfiore, E. ý\& O. Bennett. 2008. The Social Impact of the Arts: An Intellectual History. Berlin, Germany: Springer. 
Bell-Villada, Gene H. 1998. Art for Art's Sake \& Literary Life: How Politics and Markets Helped Shape the Ideology \& Culture of Aestheticism, 1790-1990. Lincoln, Nebraska: U of Nebraska Press.

Bosanquet, Bernard. 2015. The Introduction to Hegel's Philosophy of Fine Art. London: Routledge.

Bourdieu, Pierre. 1996. The Rules of Art: Genesis and Structure of the Literary Field. Redwood City, California: Stanford University Press.

Bourdieu, Pierre. 2013. Distinction: A Social Critique of the Judgement of Taste. London: Routledge.

Butler, Christopher. 2005. Pleasure and the Arts: Enjoying Literature, Painting, and Music. Oxford, England, UK: Oxford University Press.

Caudwell, Christopher. 2015. Romance and Realism: A Study in English Bourgeois Literature. Princeton, New Jersey: Princeton University Press.

Cox, Noel 2007. Being and Becoming: the Art of Mental Transformation. Magusmind.com Press. www.magusmind.com

Coulangeon, Philippe \& J ulien Duval.2014. The Routledge Companion to Bourdieu's 'Distinction'. London: Routledge.

Davis, Michael. 2011. The Soul of the Greeks: An Inquiry. Chicago, USA: University of Chicago Press.

Dutton, Denis. 2009. The Art Instinct: Beauty, Pleasure, \& Human Evolution. Oxford, England, U.K.: Oxford University Press.

Fleming, Mike, Liora Bresler, \& John O'Toole. 2014. The Routledge International Handbook of the Arts and Education. London: Routledge.

Foster, Arnold W. \& Judith R. Blau. 2011. Art and Society: Readings in the Sociology of the Art. New York: Suny Press.

Friedlander, Paul. 2015. Plato: An Introduction. Princeton, New Jersey: Princeton University Press.

Gerson, Lloyd P. 1999. Aristotle: Politics, Rhetoric and Aesthetics. Milton Park, Abingdon-on-Thames, Oxfordshire,
United Kingdom Taylor \& Francis. ISBN. $041514888 X, 9780415148887$.

Gikandi, Simon. 2012. "Realism, Romance, and the Problem of African Literary History". Modern Language Quarterly, 2012 Volume 73, Number 3: 309-328. DOI: 10.1215/00267929-1631415.

Golden, Leon. 2017. Aristotle and the Arc of Tragedy. New York: Radius Book Group.

Graham, Gordon. 2006. Philosophy of the Arts: An Introduction to Aesthetics. London: Routledge.

Halliwell, Stephen. 1986. Aristotle's Poetics. Chicago: University of Chicago Press.

Hamedi, Afifeh. 2014. "The Concept of Justice In Greek Philosophy (Plato and Aristotle)". Mediterranean Journal of Social Sciences, Vol 5 No 27, December 2014. Doi:10.5901/ mjss.2014.v5n27p1163.

Harman, Graham. 2011. Heidegger Explained: From Phenomenon to Thing. Chicago, USA: Open Court Publishing.

Hilgers, Mathieu. 2009. "Habitus, Freedom, and Reflexivity". Theory \& Psychology, Vol. 19, 2009 (6): 728-755. DOI: $10.1177 / 0959354309345892$.

Holt, Claire. 2000. Melacak Jejak Perkembangan Seni di Indonesia. Terjemahan R.M. Soedarsono. Bandung: Masyarakat Seni Pertunjukan Indonesia.

Ihde, Don. 1991. Instrumental Realism: The Interface Between Philosophy of Science and Philosophy of Technology. Bloomington, Indiana, USA: Indiana University Press.

Ivan Katchanovski, Zenon E. Kohut, Bohdan Y. Nebesio, \& Myroslav Yurkevich. 2013. Historical Dictionary of Ukraine. Lanham, Maryland, USA: Scarecrow Press.

Karyanto, Ibe. 1997. Realisme Sosialis Georg Lukacs. Jakarta: Gramedia Pustaka Utama.

Kim, Kyung-Man. 2015. Discourses on Liberation: An Anatomy of Critical Theory. London: Routledge.

Kleiner, Fred S. 2009. Gardner's Art through the Ages: Non-Western Perspectives. Boston, Massachusetts, USA: Cengage Learning. 
Kuyper, Abraham. 2009. Lectures on Calvinism. New York: Cosimo, Inc.

Laksana,A. Bagus. 2001."EstetikaEmansipatoris, Meretas Kebuntuan Zaman. Basis, Nomor 09-10, Tahun Ke-50, September-Oktober 2001.

Lazzari, Margaret \& Dona Schlesier. 2011. Exploring Art: A Global, Thematic Approach. Boston, Massachusetts, USA: Cengage Learning.

Lizardo, O. 2004, "The cognitive origins of Bourdieu's Habitus", Journal for the Theory of Social Behaviour, Vol. 34, No. 4, pp. 375-448. DOI: $10.1111 / \mathrm{j} .1468-$ 5914.2004.00255.x.

L-Maklai, Miklouho. 1988. Menguak Luka Masyarakat: Beberapa Aspek Seni Rupa Indonesia Sejak 1966. Jakarta: PT. Gramedia Pustaka Utama.

Marx, Karl. 2000. Theories of Surplus Value: Books I, II, and III. Amherst, New York: Prometheus Books.

Maxwell, Robert Allan. 2010. Representing History, 900-1300: Art, Music, History. Penn State University Press: University Park, Pennsylvania.

Meinhold, Roman 2015. "Pain and Catharsis in Art, Ritual and Therapy". Cultural Ontology of the Self in Pain, pp. 93-109. DOI 10.1007/978-81-322-2601-7_5.

McIntyre, P. J., Fulton, \& E. Paton, (eds.). 2016. The Creative System in Action: Understanding Cultural Production and Practice. Berlin: Springer.

Nash, Roy.1990. "Bourdieu on Education and Social and Cultural Reproduction". British Journal of Sociology of Education, Vol. 11, No. 4, (1990), pp. 431-447. URL: http:// www.jstor.org/stable/1392877.

Naziree, Shireen. 2013. Convergence: Past, Reality \& Future: Selected Artworks of Petronas Art Collection. Kuala Lumpur, Malaysia: Galeri Petronas.

Palmer, Allison Lee. 2011. Historical Dictionary of Romantic Art and Architecture. Lanham, Maryland: Scarecrow Press.

Prettejohn, Elizabeth. 2007. Art for Art's Sake: Aestheticism in Victorian Painting. New
Haven, Connecticut: Yale University Press for The Paul Mellon Centre for Studies in British Art.

Protschky, Susie. 2011. Images of the Tropics: Environment and Visual Culture in Colonial Indonesia. Leiden, Netherlands: BRILL.

Read, Herbert. 2000. Arti Seni dan Problematikanya. Terjemahan Soedarso, Sp. Yogyakarta: Duta Wacana Press.

Reader, Lesley \& Lucy Ridout. 2002. Bali and Lombok. London, UK: Rough Guides.

Roberts, Alexander (ed.). 2007. The AnteNicene Fathers: The Writings of the Fathers Down to A. D. 325 Volume II - Fathers of the Second Century-Hermas, Tatian, Theophilus, Athenago. New York: Cosimo, Inc.

Rothenberg, Julia. 2014. Sociology Looks at the Arts. London: Routledge.

Scaramuzzo, Gilberto. 2016. "Aristotle's Homo Mimeticus as an Educational Paradigm for Human Coexistence". Journal of Philosophy of Education. Volume 50, Issue 2, May 2016, Pages 246-260. DOI: 10.1111/1467-9752.12204.

Şenol, Ajda. 2014. "Is Art Mimesis or Creation?". Procedia-Social and Behavioral Sciences 116 (2014) 2866-2870.

Sp., Soedarso. 1988. Tinjauan Seni: Sebuah Pengantar untuk Apresiasi Seni. Yogyakarta: Saku Dayar Sana.

Spielmann, Yvonne. 2017. Contemporary Indonesian Art: Artists, Art Spaces, and Collectors. Singapore: NUS Press.

Stone, David M. 2017. Caravaggio: Reflections and Refractions. London: Routledge.

Vickers, Adrian. 2012. Balinese Art: Paintings and Drawings of Bali 1800-2010.

North Clarendon, Vermont: Tuttle Publishing.

Walker, Ray Van De. 2012. How to be Good: The Science of Doing Well. BookBaby.

Wilkinson, Tony J. 2003. Archaeological Landscapes of the Near East. Tucson, Arizona, USA: University of Arizona Press.

Winner, Ellen Thalia R. Goldstein and Stéphan Vincent-Lancrin. 2013. Art for Art's Sake? The Impact Of Arts Education. Paris, 
France: OECD Publishing. http://dx.doi. Wolfe, M. Melissa. 2017. George Bellows org/10.1787/9789264180789-en.

Wiryomartono, Bagoes P. 2001. Pijar-pijar Penyingkap Rasa: Sebuah Wacana Seni dan Keindahan dari Plato sampai Derrida. Jakarta: PT Gramedia. Revisited: New Considerations of the Painter's Oeuvre. Cambridge: Cambridge Scholars Publishing.

Wolff, Janet. 1981. The Social Producton of Art. New York: St. Martin's Press, Inc. 